\title{
A Model of Quality of Work Life, Life Satisfaction and Service Quality
}

\author{
Mahadzirah Mohamad \\ Wan Norhayati Mohamed \\ Universiti Malaysia Terengganu
}

\begin{abstract}
The study was conducted with the purpose of identifying the impact of Quality of Work Life (QWL) on Life Satisfaction (LS) and Service Quality (SQ) among nurses in the public hospitals. Exploratory factor analysis (EFA) and confirmatory factor analysis (CFA) were used to examine the internal reliability of a measure and structural equation modelling (SEM) was used to test the goodness of the proposed hypothesised model. The findings of the study supported the first two proposed hypotheses that postulated firstly, that the higher the perceived QWL, the higher the LS and, secondly, the higher the perceived QWL, the higher the perceived nursing SQ. The third hypothesis stated that the higher the LS, the higher the nursing SQ was not supported. The implication of the study suggests that nursing staff with high quality of QWL would deliver high SQ and at the same time achieve high LS.
\end{abstract}

Keywords: Quality of Work Life, Life Satisfaction, Service Quality

\section{Introduction}

Research on Quality of Work Life (QWL) started in the early 1970s (Saklani, 2004) and studies on it are essential to help organisations identify gaps that could improve employee's QWL since high QWL could attract and retain employees (Sandrick, 2003). This is especially crucial in the case of the Malaysian public health-care sector. The demand for public health-care service is increasing and this creates a greater need for health-care services personnel. Consequently, the government is facing a great challenge to ensure sufficient personnel and financial resources are in place to satisfy the demand. With society becoming more affluent, the general public demands a better quality of life, hence the basic level of the health-care services is no longer sufficient to meet the escalating needs for quality health-care services. In a situation where the industry is facing a shortage of trained staff, it is important to ensure that a high performance of the current workforce is achieved.

Undoubtedly, it is challenging to provide a high-quality nursing service when the sector is confronted with a shortage of trained staff. In addition, greater wages and 
benefits offered by other counterparts in the local private sector and developed foreign countries, especially the Middle-East, were argued to be the possible contributing factors that worsen the situation. However, some argue that compensation and benefit strategies are short term in nature. Perhaps it is more relevant to focus on planning long-term strategies that concentrate on improving QWL which is said to be a more practical and long-term approach in improving hospital nurse retention. The current shortage of nurses in Malaysia highlights the importance of understanding their work environment, giving emphasis to the different aspects of QWL, so that relevant policies can be formulated to retain them in the workforce and provide quality service. This study attempts to study nurses' QWL, its relationship with nurses' Life Satisfaction (LS) and the quality of their health-care service delivery.

\section{Quality of Work Life, Life Satisfaction and Service Quality}

The QWL construct is complex as it comprises of both physical and mental wellbeing of employees (Lawler, 1982). In general, the definitions of QWL focus on the good feeling perceived from the interaction between the individuals and their work environment. The definition by Hackman and Oldhams (1980) described QWL in relation to the interaction between work environment and personal needs and is the extent to which employees can enhance their personal lives through their work environment and experiences. Sirgy et al. (2001) postulated that people have sets of needs which they seek to fulfil at their workplace. Parallel to the previous definition, Haskett et al. (1997) advocated that QWL is the feelings that employees have towards their jobs, colleagues and organisations that stimulate organisations' growth and profitability. In addition, Sirgy et al. (2001) suggested that the outcomes of QWL are job satisfaction and other life domains termed as LS, as postulated by Beutell (2006). The Spillover Theory is useful to explain how satisfaction in work life can influence satisfaction in other life domains (such as LS) and deliver quality service (Md-Sidin and Sambasivan, 2010). According to Sirgy et al. (2001), there are two types of Spillover Theory: horizontal and vertical spillover. Horizontal spillover explains the effect of one life domain on other life domains. For example, job satisfaction has an influence on personal life, family life, social life and leisure life. On the other hand, vertical spillover helps to explain the effect of life domains that are perceived by individuals to be organized in hierarchical order. Therefore, it is postulated that individuals with high QWL will attain a harmonious balance between career and personal lives. Similarly, Spillover Theory also explains the influence of LS on the delivering of SQ. Although Beutell (2006) suggested that LS, which is the non-work variable, could affect employees' withdrawal behaviour, it is argued that it may also influence employees other behaviours such as delivering quality service during service encounters. Therefore, it is the main aim of the present study to develop such a model of QWL, LS and SQ.

Life Satisfaction (LS) is one of the major components of subjective well-being, and both concepts with different levels of specificity, refer to the summation of evaluations regarding a person's life as a whole (Vitterso et al., 2005). Pavot and Diener, (1993) argued that LS is a conscious cognitive judgement of one's life in which criteria for judgement are up to the person. Moreover, Rice (1984) described overall LS as the degree to which an individual's life experience satisfies the 
individual's needs and wants in different life domains, for example as an employee, parent, spouse and friend. Furthermore, LS is not considered a permanent or objective trait of an individual, but is rather sensitive to contextual change and is considered from the point of view of respondents themselves (Swami \& Chamorro-Premuzic, 2009). The recent work of Beutell (2006) suggested that satisfaction assessment on the different aspects of work is identified as job satisfaction and non-work domain is labelled as LS. Thus, satisfaction in the non-work domain would mean satisfaction in aspects of other life domains which exclude job satisfaction and, according to Sirgy et. al (2001), these include aspects related to family, leisure, health, education, friendship, cultural and social status. It is noted that the link between job satisfaction and LS is undoubted (Demaerouti et al., 2000). Therefore, one of the main objectives of this study is to generate a model that provides a useful insight of improving LS through changes in QWL.

Service Quality (SQ) is a multiple-dimension construct (Parasuraman et al., 1985) and different authors suggested different dimensions. Lethinen and Lethinen (1982) defined SQ as comprising three dimensions: physical quality, interactive quality and corporate (image) quality. Parasuraman et al., (1988), however proposed five dimensions of SQ (reliability, assurance, tangibility, empathy and responsiveness). Sureshchandar et al. (2001) identified five factors of SQ, namely core service or service product; human element of service delivery; systematisation of service delivery: non-human element; tangibles of service (servicescapes) and social responsibility. There is evidence that QWL may have a significant impact on employee behavioural responses (Sirgy et al., 2001) such as job performance (delivering quality service during service encounters) and intention to quit. According to Kotler et al. (2009), the concept of internal marketing should be applied within organisations to enable employees to serve customers well. Berry and Parasuraman (1991) proposed internal marketing as the management philosophy of treating employees as customers. Therefore, organisations should meet the needs of the employees before meeting customer's needs. It is proposed that satisfied employees will be more productive and give satisfactory services to customers.

\section{Methods}

Currently, there are 45,060 registered nurses working in public hospitals (Ministry of Health Malaysia, 2009). The population of this study consists of registered nurses working at the Obstetrics and Gynecology, and Pediatric Department in the statelevel public hospitals. These state-level hospitals provide a comprehensive range of secondary-care services and also function as referral centres for other hospitals in the respective state. They are the largest hospitals in the respective state with a bed capacity of more than 600 (Manaf, 2005). Referring to the Krejie and Morgan sample-size table (Sekaran, 2006), a sample size of 357 was considered large enough. Using the Burns and Bush (2010) sample-size formula, the adequate sample size for the study was 221 respondents. To conduct Structural Equation Modelling (SEM), Garver \& Mentzer, and Hoelter, in (Hoe, 2008), proposed a 'critical sample size' of 200. In other words, as a rule of thumb, any number above 200 is understood to provide sufficient statistical power for data analysis. 
The selection of respondents involved two steps. First, using area-sampling technique, four state-level hospitals were selected and 300 questionnaires were distributed to each hospital. A total of 800 questionnaires were returned representing a $67 \%$ response rate. Second, a sampling frame was created using the returned questionnaires. From the created sampling frame, a total of 400 nurses were selected for the study using a random-sampling method. After a data cleaning process, a total of 392 respondent's questionnaires were subjected for further analysis.

The research instrument developed by Brooks and Anderson (2005) was used in this study to measure nurses' Quality of Work Life (NQWL). The NQWL consists of 42 items and measures four dimensions of NQWL: "work life-home life", work design, work context, and work world. LS was measured using a five-item satisfaction with life scale (SWLS) developed by Diener et al., (1985). The SWLS assessed the concept of LS by measuring individuals' global judgement of their lives. The SWLS has been widely used for the past 20 years since its development in more than 4,000 studies (Gouveia et al., 2009). The SWLS has been translated into Malay (Swami and Chamorro-Premuzic, 2009), Chinese (Sachs, 2004), Arabic (Abdullah, 1998), Dutch (Arrindell et al., 1999), Norwegian (Vitterso et al., 2005) and Spanish (Atienza et al, 2003). The factor structure, reliability and validity of SWLS have been supported in past studies (Swami and Chamorro-Premuzic, 2009; Diener et al.,1985). The 22 items of modified version of SERVQUAL developed by Lee and Yom (2007) was used in this study to measure nursing SQ in the public hospital. Lee and Yom (2007) have modified the instrument to make it more suitable to the nursing services. The SERVQUAL scale has been used in a wide variety of studies in health-care to assess perceptions of SQ in a number of service categories such as nursing homes (Kilbourne et al., 2004), colposcopy clinics (Wisniewski, 2005), hospitals (Taner and Anthony, 2006).

\section{Results}

Analysis of the data revealed that the majority of the respondents were female (99\%), reflecting the population of nursing staff in Malaysia, and married (72\%). The majority of them had obtained a Diploma in nursing and was aged between 25 and 34 years old. Their children ranged from 1 to 4 . Almost $60 \%$ of the respondents had served in the public health-care institutions for less than 10 years and only $8 \%$ of them had worked for a period of 21 to 25 years. This implies that there is a high nursing staff turnover within the sector.

The exploratory factor analysis (EFA) was performed to determine the underlying dimensions of QWL and SQ. The results of Barlett's test of sphericity are significant and the values of Kaiser-Meyer-Olkin (KMO) measure of sampling adequacy are 0.91 and 0.91 for QWL and SQ respectively. QWL components loaded into two underlying factors termed as "communication and opportunities for career growth" and "work-family life balance". These factors explained $64 \%$ of the variation in QWL. SQ component also loaded into two underlying factors labelled as "empathy" and "reliability". These factors explained $82 \%$ of the variation in SQ. LS is manifested by four observed exogenous items. Reliability tests conducted on QWL, SQ and LS produced Cronbach's alpha values of 0.91, 0.95 and 0.94 respectively. The values of item-total correlation as illustrated in Table I, Table II and Table III for 
QWL, SQ and LS respectively are more than 0.3, suggesting that these items correlate very well with the scale overall (Field, 2009). Unidimensionality of the underlying factors was assessed using factor loading of retained items from EFA. Factor loadings for all items of the identified factors are greater than 0.5 , indicating that these items are associated with the underlying factors (Hair et al., 2010).

Table I: Quality of Work Life Item-Total Correlation

\begin{tabular}{|l|c|c|c|c|c|}
\hline & $\begin{array}{c}\text { Scale } \\
\text { Mean } \\
\text { if Item } \\
\text { Deleted }\end{array}$ & $\begin{array}{c}\text { Scale } \\
\text { Variance } \\
\text { if Item } \\
\text { Deleted }\end{array}$ & $\begin{array}{c}\text { Corrected } \\
\text { Item-Total } \\
\text { Correlation }\end{array}$ & $\begin{array}{c}\text { Squared } \\
\text { Multiple } \\
\text { Correlation }\end{array}$ & $\begin{array}{c}\text { Cronbach's } \\
\text { Alpha if } \\
\text { Item } \\
\text { Deleted }\end{array}$ \\
\hline $\begin{array}{l}\text { I am able to balance work with } \\
\text { my family needs (W1) }\end{array}$ & 33.33 & 35.24 & 0.64 & .446 & 0.908 \\
\hline $\begin{array}{l}\text { I am able to arrange for day care } \\
\text { for my elderly parents (W5) }\end{array}$ & 33.82 & 33.68 & 0.64 & .595 & 0.909 \\
\hline $\begin{array}{l}\text { I am able to arrange for day care } \\
\text { when my child is sick (W6) }\end{array}$ & 34.02 & 34.79 & 0.62 & .546 & 0.909 \\
\hline $\begin{array}{l}\text { I am able to communicate well } \\
\text { with my nurse } \\
\text { manager/supervisor (W15) }\end{array}$ & 33.30 & 34.35 & 0.71 & .560 & 0.903 \\
\hline $\begin{array}{l}\text { My work setting provides career } \\
\text { advancement opportunities } \\
\text { (W19) }\end{array}$ & 33.49 & 33.02 & 0.78 & .635 & 0.898 \\
\hline $\begin{array}{l}\text { I feel like I belong to the “work } \\
\text { family” (W21) }\end{array}$ & 33.35 & 33.65 & 0.78 & .650 & 0.898 \\
\hline $\begin{array}{l}\text { I am able to communicate with } \\
\text { other therapists (physical, } \\
\text { respiratory, etc.) (W22) }\end{array}$ & 33.49 & 34.48 & 0.68 & .526 & 0.905 \\
\hline $\begin{array}{l}\text { I am able to participate in } \\
\text { decision made by my nurse } \\
\text { supervisor/manager (W24) }\end{array}$ & 33.74 & 33.41 & 0.71 & .549 & 0.903 \\
\hline $\begin{array}{l}\text { I am recognised for my } \\
\text { accomplishments by my nurse } \\
\text { manager/supervisor (W28) }\end{array}$ & 33.63 & 33.13 & 0.76 & .620 & 0.899 \\
\hline
\end{tabular}

Table II: Service Quality Item-Total Correlation

\begin{tabular}{|l|c|c|c|c|c|}
\hline & $\begin{array}{c}\text { Scale } \\
\text { Mean } \\
\text { if Item } \\
\text { Deleted }\end{array}$ & $\begin{array}{c}\text { Scale } \\
\text { Variance } \\
\text { if Item } \\
\text { Deleted }\end{array}$ & $\begin{array}{c}\text { Corrected } \\
\text { Item-Total } \\
\text { Correlation }\end{array}$ & $\begin{array}{c}\text { Squared } \\
\text { Multiple } \\
\text { Correlation }\end{array}$ & $\begin{array}{c}\text { Cronbach's } \\
\text { Alpha if } \\
\text { Item } \\
\text { Deleted }\end{array}$ \\
\hline $\begin{array}{l}\text { Provide nursing service in well- } \\
\text { equipped facilities (S3) }\end{array}$ & 33.07 & 26.93 & 0.68 & 0.61 & 0.951 \\
\hline $\begin{array}{l}\text { Provide good feeling because of } \\
\text { appearance (S4) }\end{array}$ & 32.72 & 26.45 & 0.86 & 0.81 & 0.939 \\
\hline $\begin{array}{l}\text { Provide precise nursing services } \\
\text { (S5) }\end{array}$ & 32.81 & 26.63 & 0.83 & 0.82 & 0.940 \\
\hline $\begin{array}{l}\text { Provide skillful nursing services } \\
\text { (S6) }\end{array}$ & 32.71 & 26.47 & 0.82 & 0.76 & 0.941 \\
\hline $\begin{array}{l}\text { Help patient willingly whenever } \\
\text { help is needed (S12) }\end{array}$ & 32.45 & 26.79 & 0.78 & 0.66 & 0.943 \\
\hline
\end{tabular}




\begin{tabular}{|l|c|c|c|c|c|}
\hline Induce emotional comfort (S21) & 32.48 & 26.48 & 0.82 & 0.85 & 0.941 \\
\hline Respect patient's feeling (S22) & 32.35 & 26.28 & 0.86 & 0.92 & 0.938 \\
\hline $\begin{array}{l}\text { Listen to patient's complaints } \\
\text { (S23) }\end{array}$ & 32.32 & 26.38 & 0.85 & 0.90 & 0.939 \\
\hline
\end{tabular}

Table III: Life Satisfaction Item-Total Correlation

\begin{tabular}{|l|c|c|c|c|c|}
\hline & $\begin{array}{c}\text { Scale } \\
\text { Mean } \\
\text { if Item } \\
\text { Deleted }\end{array}$ & $\begin{array}{c}\text { Scale } \\
\text { Variance } \\
\text { if Item } \\
\text { Deleted }\end{array}$ & $\begin{array}{c}\text { Corrected } \\
\text { Item-Total } \\
\text { Correlation }\end{array}$ & $\begin{array}{c}\text { Squared } \\
\text { Multiple } \\
\text { Correlation }\end{array}$ & $\begin{array}{c}\text { Cronbach's } \\
\text { Alpha if } \\
\text { Item } \\
\text { Deleted }\end{array}$ \\
\hline $\begin{array}{l}\text { In most ways, my life is close to } \\
\text { my ideal (L1) }\end{array}$ & 12.38 & 6.45 & 0.840 & .720 & 0.926 \\
\hline $\begin{array}{l}\text { The conditions of my life are } \\
\text { excellent (L2) }\end{array}$ & 12.54 & 6.24 & 0.886 & .790 & 0.911 \\
\hline I am satisfied with my life (L3) & 12.43 & 6.51 & 0.885 & .786 & 0.913 \\
\hline $\begin{array}{l}\text { So far I have gotten the } \\
\text { important things I want in life } \\
\text { (L4) }\end{array}$ & 12.58 & 6.37 & 0.817 & .677 & 0.934 \\
\hline
\end{tabular}

Hair et al. (2010) suggested that convergent validity is assessed using construct reliability (CR) and the average variance extracted (AVE). The calculated CR and AVE for all four latent constructs surpassed the threshold value of 0.7 and 0.5 respectively. The AVE values for the latent constructs was compared to the squared correlations between the corresponding constructs to examine the discriminant validity of the measurement model (Fornell and Larcker, 1981) and none of the squared correlation surpassed the AVE. The above test indicated that the discriminant validity is secured (see Table IV).

Table IV: Results for Measurement Model

\begin{tabular}{|l|c|c|c|}
\hline Constructs & $\begin{array}{l}\text { Construct } \\
\text { Reliability (CR }\end{array}$ & $\begin{array}{l}\text { Average Variance } \\
\text { Extracted (AVE) }\end{array}$ & $\begin{array}{l}\text { Squared } \\
\text { Correlation } \\
\text { Estimate }\end{array}$ \\
\hline Quality of Work Life & \multirow{2}{*}{0.51} \\
\hline $\begin{array}{l}\text { Communication and } \\
\text { Opportunities for Career } \\
\text { Growth }\end{array}$ & 0.91 & 0.54 & \\
\hline $\begin{array}{l}\text { Work-Family Life } \\
\text { Balance }\end{array}$ & 0.76 & 0.53 & \multirow{2}{*}{0.55} \\
\hline Service Quality & \multicolumn{3}{|c|}{} \\
\hline Reliability & 0.88 & 0.65 & \\
\hline Empathy & 0.90 & 0.71 & \\
\hline
\end{tabular}


Figure 1: Structural Model of QWL, LS and SQ

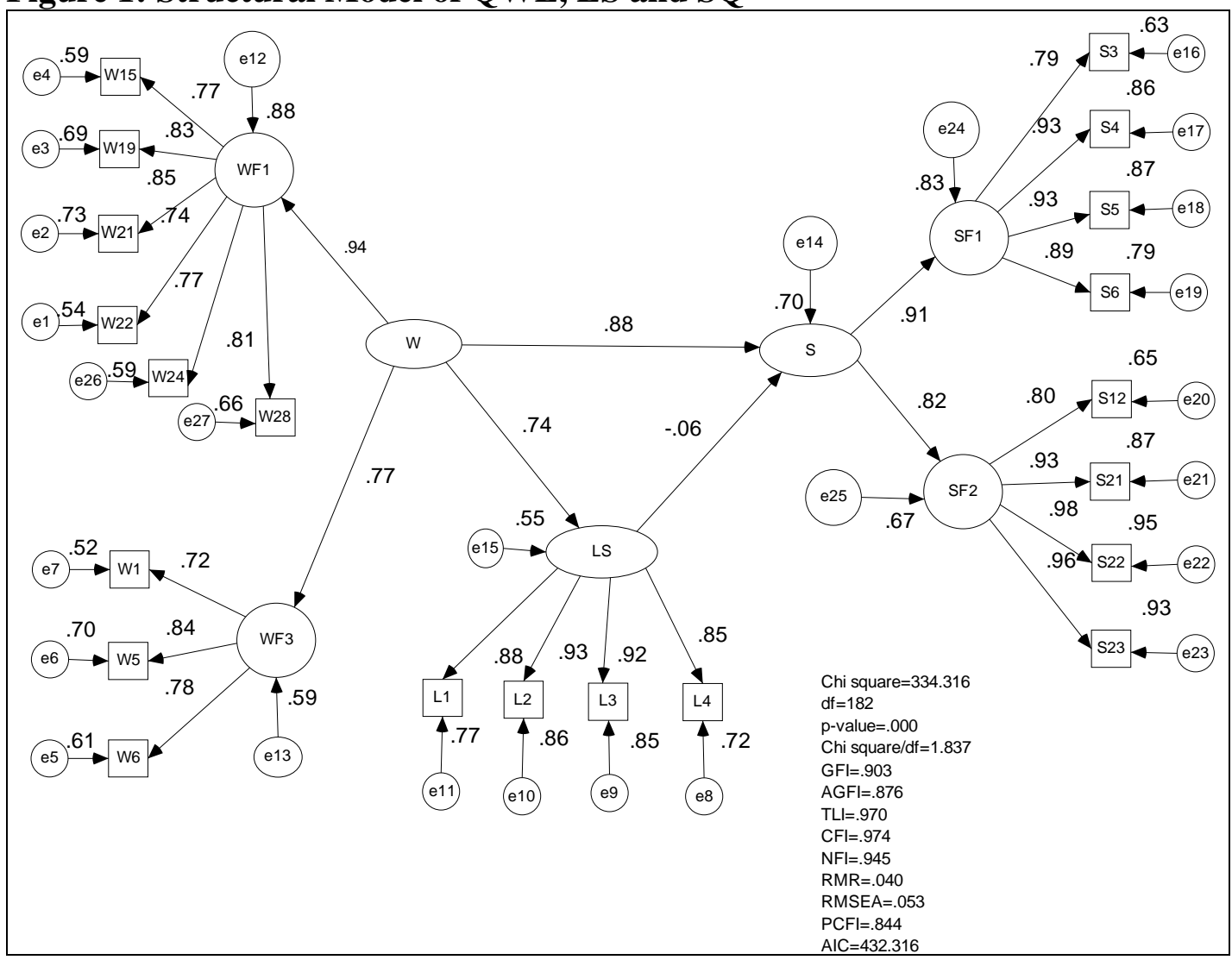

Note: W = Quality of Work Life, LS = Life Satisfaction, S = Service Quality

\section{Research Model}

Figure 1 illustrates the structural model of QWL, LS and SQ. Universally-accepted statistical indexes such as Goodness-of-Fit Index (GFI) and Adjusted Goodness-ofFit Index (AGFI) were used to assess the goodness-of-fit of the proposed model, with values closer to 1 indicating good fit (Byrne, 2009). The values of Goodness-of-Fit Index (GFI) and Adjusted Goodness-of-Fit Index (AGFI) attained for the proposed model are 0.90 and 0.88 respectively. It is therefore concluded that the hypothesised model proposed in the study fits the sample data adequately well. The value of Root Mean Square Residual (RMR) for the proposed model is 0.04 , less than 0.05 , and also describes a well-fitting model. Baseline comparisons indexes, Normed Fit Index (NFI), Tucker-Lewis Index (TLI) and Comparative Fit Index (CFI) are another sets of goodness-of-fit statistics are used to support the fitness of the hypothesised model. The value of Normed Fit Index (NFI), Tucker-Lewis Index (TLI) and Comparative Fit Index (CFI) ranges from 0 to 1 , with values closer to 1.00 being indicative of good fit (Byrne, 2009). In this case, NFI, TLI and CFI values of 0.95, 0.97 and 0.97 respectively are consistent in suggesting that the hypothesised model represented an adequate fit to the data. The value of Root Mean Square Error of the Approximation (RMSEA) for the proposed model is 0.05 ; less than 0.08 indicates reasonable error of approximation implying that the model is acceptably fit (Hair et al, 2010). Based on the above goodness-of-fit statistics, there are enough supports to conclude that the 
hypothesised model fits the data gathered adequately well and further analysis can be done.

\section{Relationships among Constructs}

The path coefficients for the full model are as illustrated in Table V. Path coefficients are positive and have significant (p-value $<0.05$ ), except for the path coefficient between LS and SQ which is not significant. Table VI indicates the standardised regression weights ( $ß$ ) that illustrate the measures of strength and magnitude of the associations between variables examined in this study. The results indicated that there are positive significant relationships between QWL and SQ; and QWL and LS. However, there is no significant relationship between LS and SQ.

Table V: Regression Weights

\begin{tabular}{|c|c|c|c|c|c|c|}
\hline Construct & Path & Construct & Est & S.E. & C.R. & $\mathrm{P}$ \\
\hline Life Satisfaction (LS) & $<---$ & $\begin{array}{l}\text { Quality of Work } \\
\text { Life (QWL) }\end{array}$ & .832 & .083 & $\begin{array}{r}10.0 \\
70\end{array}$ & $\begin{aligned} * * \\
*\end{aligned}$ \\
\hline Service Quality (SQ) & $<---$ & $\begin{array}{l}\text { Quality of Work } \\
\text { Life (QWL) }\end{array}$ & .823 & .122 & $\begin{array}{r}6.75 \\
0 \\
\end{array}$ & $\begin{aligned} * * \\
* \\
\end{aligned}$ \\
\hline Service Quality (SQ) & $<---$ & $\begin{array}{l}\text { Life Satisfaction } \\
\text { (LS) }\end{array}$ & -.046 & .082 & $\begin{array}{r}- \\
.567\end{array}$ & $\begin{array}{r}.5 \\
70\end{array}$ \\
\hline Communication (WF1) & $<--$ & $\begin{array}{l}\text { Quality of Work } \\
\text { Life }\end{array}$ & 1.000 & & & \\
\hline Work-Family (WF2) & $<---$ & $\begin{array}{l}\text { Quality of Work } \\
\text { Life }\end{array}$ & .793 & .080 & $\begin{array}{r}9.89 \\
1\end{array}$ & $\begin{aligned} * * \\
*\end{aligned}$ \\
\hline Reliability (SF1) & $<<---$ & Service Quality & 1.000 & & & \\
\hline Empathy (SF2) & $<---$ & Service Quality & .836 & .076 & $\begin{array}{r}10.9 \\
31\end{array}$ & $\begin{aligned} * * \\
*\end{aligned}$ \\
\hline $\begin{array}{l}\text { I am able to participate in decision made by } \\
\text { my nurse supervisor/manager (W24) }\end{array}$ & $<---$ & $\begin{array}{l}\text { Communication } \\
\text { (WF1) }\end{array}$ & 1.000 & & & \\
\hline $\begin{array}{l}\text { I feel like I belong to the "work family" } \\
\text { (W21) }\end{array}$ & $<---$ & $\begin{array}{l}\text { Communication } \\
\text { (WF1) }\end{array}$ & .998 & .063 & $\begin{array}{r}15.7 \\
51 \\
\end{array}$ & $\begin{aligned} * * \\
* \\
\end{aligned}$ \\
\hline $\begin{array}{l}\text { My work setting provides career } \\
\text { advancement opportunities (W19) }\end{array}$ & $<---$ & $\begin{array}{l}\text { Communication } \\
\text { (WF1) }\end{array}$ & 1.042 & .069 & $\begin{array}{r}15.2 \\
06 \\
\end{array}$ & $\begin{aligned} * * \\
* \\
\end{aligned}$ \\
\hline $\begin{array}{l}\text { I am able to communicate well with my } \\
\text { nurse manager/supervisor (W15) }\end{array}$ & $<---$ & $\begin{array}{l}\text { Communication } \\
\text { (WF1) }\end{array}$ & .900 & .065 & $\begin{array}{r}13.9 \\
12\end{array}$ & $\begin{aligned} * * \\
* \\
\end{aligned}$ \\
\hline \begin{tabular}{|l|} 
I am able to communicate with other \\
therapists (physical, respiratory, etc.) (W22)
\end{tabular} & $<---$ & $\begin{array}{l}\text { Communication } \\
\text { (WF1) }\end{array}$ & .873 & .066 & $\begin{array}{r}13.1 \\
89 \\
\end{array}$ & $\begin{array}{r}* * \\
* \\
\end{array}$ \\
\hline $\begin{array}{l}\text { I am recognised for my accomplishments by } \\
\text { my nurse manager/supervisor (W28) }\end{array}$ & $<---$ & $\begin{array}{l}\text { Communication } \\
\text { (WF1) }\end{array}$ & 1.034 & .070 & $\begin{array}{r}14.8 \\
41 \\
\end{array}$ & $\begin{array}{r}* * \\
* \\
\end{array}$ \\
\hline $\begin{array}{l}\text { I am able to arrange for day care when my } \\
\text { child is sick (W6) }\end{array}$ & $<---$ & $\begin{array}{l}\text { Work-Family } \\
\text { (WF2) }\end{array}$ & 1.000 & & & \\
\hline $\begin{array}{l}\text { I am able to arrange for day care for my } \\
\text { elderly parents (W5) }\end{array}$ & $<---$ & $\begin{array}{l}\text { Work-Family } \\
\text { (WF2) }\end{array}$ & 1.190 & .086 & $\begin{array}{r}13.8 \\
67 \\
\end{array}$ & $\begin{aligned} * * \\
* \\
\end{aligned}$ \\
\hline $\begin{array}{l}\text { I am able to balance work with my family } \\
\text { needs (W1) }\end{array}$ & $<---$ & $\begin{array}{l}\text { Work-Family } \\
\text { (WF2) }\end{array}$ & .846 & .069 & $\begin{array}{r}12.1 \\
71 \\
\end{array}$ & $\begin{aligned} * * \\
* \\
\end{aligned}$ \\
\hline $\begin{array}{l}\text { So far I have gotten the important things I } \\
\text { want in life (L4) }\end{array}$ & $<---$ & $\begin{array}{l}\text { Life Satisfaction } \\
\text { (LS) }\end{array}$ & 1.000 & & & \\
\hline I am satisfied with my life (L3) & $<---$ & Life Satisfaction & .991 & .045 & 21.8 & $* *$ \\
\hline
\end{tabular}




\begin{tabular}{|l|c|l|l|r|r|r|}
\hline \multicolumn{1}{|c|}{ Construct } & Path & \multicolumn{1}{|c|}{ Construct } & Est & S.E. & C.R. & P \\
\hline The conditions of my life are excellent (L2) & $<---$ & $\begin{array}{l}\text { Life Satisfaction } \\
\text { (LS) }\end{array}$ & 1.060 & .048 & $\begin{array}{r}22.0 \\
32\end{array}$ & $\begin{array}{r}* * \\
*\end{array}$ \\
\hline $\begin{array}{l}\text { In most ways, my life is close to my ideal } \\
\text { (L1) }\end{array}$ & $<---$ & $\begin{array}{l}\text { Life Satisfaction } \\
\text { (LS) }\end{array}$ & .994 & .050 & $\begin{array}{r}19.9 \\
33\end{array}$ & $\begin{array}{r}* * \\
*\end{array}$ \\
\hline $\begin{array}{l}\text { Provide nursing service in well-equipped } \\
\text { facilities (S3) }\end{array}$ & $<---$ & Reliability (SF1) & 1.000 & & & \\
\hline $\begin{array}{l}\text { Provide good feeling because of appearance } \\
\text { (S4) }\end{array}$ & $<---$ & Reliability (SF1) & 1.039 & .055 & $\begin{array}{r}18.9 \\
35\end{array}$ & $\begin{array}{r}* * \\
*\end{array}$ \\
\hline Provide precise nursing services (S5) & $<---$ & Reliability (SF1) & 1.053 & .055 & $\begin{array}{r}19.1 \\
38\end{array}$ & $\begin{array}{r}* * \\
*\end{array}$ \\
\hline Provide skillful nursing services (S6) & $<---$ & Reliability (SF1) & 1.026 & .058 & $\begin{array}{r}17.7 \\
67\end{array}$ & $\begin{array}{r}* * \\
*\end{array}$ \\
\hline $\begin{array}{l}\text { Help patient willingly whenever help is } \\
\text { needed (S12) }\end{array}$ & $<---$ & Empathy (SF2) & 1.000 & & & \\
\hline Induce emotional comfort (S21) & $<---$ & Empathy (SF2) & 1.160 & .057 & $\begin{array}{r}20.2 \\
01\end{array}$ & $\begin{array}{r}* * \\
*\end{array}$ \\
\hline Respect patient's feeling (S22) & $<---$ & Empathy (SF2) & 1.201 & .055 & $\begin{array}{r}21.8 \\
27\end{array}$ & $\begin{array}{r}* * \\
*\end{array}$ \\
\hline Listen to patient's complaints (S23) & $<---$ & Empathy (SF2) & 1.181 & .055 & $\begin{array}{r}21.3 \\
30\end{array}$ & $\begin{array}{r}* * \\
*\end{array}$ \\
\hline
\end{tabular}

Table VI: Standardised Regression Weights

\begin{tabular}{|l|c|l|c|}
\hline \multicolumn{2}{|c|}{ Construct } & \multicolumn{1}{|c|}{ Construct } & Est. \\
\hline Life Satisfaction (LS) & $<--$ & $\begin{array}{l}\text { Quality of Work Life } \\
\text { (QWL) }\end{array}$ & .745 \\
\hline Service Quality (SQ) & $<--$ & $\begin{array}{l}\text { Quality of Work Life } \\
\text { (QWL) }\end{array}$ & .877 \\
\hline Service Quality (SQ) & $<---$ & Life Satisfaction (LS) & -.055 \\
\hline Communication (WF1) & $<---$ & $\begin{array}{l}\text { Quality of Work Life } \\
\text { (QWL) }\end{array}$ & .938 \\
\hline Work-Family (WF2) & $<--$ & $\begin{array}{l}\text { Quality of Work Life } \\
\text { (QWL) }\end{array}$ & .769 \\
\hline Reliability (SF1) & $<---$ & Service Quality (SQ) & .911 \\
\hline Empathy (SF2) & $<---$ & Service Quality (SQ) & .819 \\
\hline $\begin{array}{l}\text { I am able to participate in decision made by my } \\
\text { nurse supervisor/manager (W24) }\end{array}$ & $<---$ & Communication (WF1) & .768 \\
\hline I feel like I belong to the “work family” (W21) & $<---$ & Communication (WF1) & .854 \\
\hline $\begin{array}{l}\text { My work setting provides career advancement } \\
\text { opportunities (W19) }\end{array}$ & $<---$ & Communication (WF1) & .829 \\
\hline $\begin{array}{l}\text { I am able to communicate well with my nurse } \\
\text { manager/supervisor (W15) }\end{array}$ & $<---$ & Communication (WF1) & .770 \\
\hline $\begin{array}{l}\text { I am able to communicate with other therapists } \\
\text { (physical, respiratory, etc.) (W22) }\end{array}$ & $<---$ & Communication (WF1) & .736 \\
\hline $\begin{array}{l}\text { I am recognised for my accomplishments by my } \\
\text { nurse manager/supervisor (W28) }\end{array}$ & $<---$ & Communication (WF1) & .813 \\
\hline I am able to arrange for day care when my child & $<---$ & Work-Family (WF2) & .784 \\
\hline
\end{tabular}




\begin{tabular}{|l|l|l|c|}
\hline \multicolumn{2}{|c|}{ Construct } & \multicolumn{1}{|c|}{ Construct } & Est. \\
\hline is sick (W6) & $<---$ & \multicolumn{1}{|c|}{ Work-Family (WF2) } & .840 \\
\hline $\begin{array}{l}\text { I am able to arrange for day care for my elderly } \\
\text { parents (W5) }\end{array}$ & $<---$ & Work-Family (WF2) & .724 \\
\hline $\begin{array}{l}\text { I am able to balance work with my family needs } \\
\text { (W1) }\end{array}$ & $<---$ & Life Satisfaction (LS) & .850 \\
\hline $\begin{array}{l}\text { So far I have gotten the important things I want } \\
\text { in life (L4) }\end{array}$ & $<---$ & Life Satisfaction (LS) & .921 \\
\hline I am satisfied with my life (L3) & $<---$ & Life Satisfaction (LS) & .926 \\
\hline The conditions of my life are excellent (L2) & $<---$ & Life Satisfaction (LS) & .878 \\
\hline In most ways, my life is close to my ideal (L1) & $<---$ & Reliability (SF1) & .791 \\
\hline $\begin{array}{l}\text { Provide nursing service in well-equipped } \\
\text { facilities (S3) }\end{array}$ & $<---$ & Reliability (SF1) & .927 \\
\hline Provide good feeling because of appearance (S4) & $<---$ & Reliability (SF1) & .934 \\
\hline Provide precise nursing services (S5) & $<---$ & Reliability (SF1) & .886 \\
\hline Provide skillful nursing services (S6) & $<---$ & Empathy (SF2) & .804 \\
\hline $\begin{array}{l}\text { Help patient willingly whenever help is needed } \\
\text { (S12) }\end{array}$ & $<---$ & Empathy (SF2) & .932 \\
\hline Induce emotional comfort (S21) & $<---$ & Empathy (SF2) & .977 \\
\hline Respect patient's feeling (S22) & $<---$ & Empathy (SF2) & .963 \\
\hline Listen to patient's complaints (S23) & & \\
\hline
\end{tabular}

\section{Discussion and Conclusions}

The results of this study can provide insights to help decision-makers in identifying key workplace issues from employees' perspectives in their initiatives to develop strategies that would address and improve the conditions of employees' QWL within each of the individual health-care organisations and assist them to manage employees' performance. The study suggests that paying attention to the different aspects of QWL which are related to employees' needs for communication and opportunities for career advancement; and work-family life balance would result in them achieving high LS and deliver reliable and empathetic services.

Findings of this study also suggest that LS and SQ are the outcomes of nurses' QWL. Nurses with high QWL appear to achieve high LS. They are described as those who perceived their life conditions as excellent, leading almost an ideal way of life and are satisfied with their life. Moreover, nurses with high QWL also appear to be delivering high SQ. They are described as providing empathy services such as understanding patient's feelings, inducing emotional comforts and providing courage and hopes to patients. They are also described as providing reliable services such as providing medications and giving treatments at the correct time. Interestingly, the findings support the Spillover Theory that explains the effect of one life domain (QWL) on other life domains (LS and SQ). However, LS has no significant influence on SQ. Beutell (2006) suggested that the non-work variable, in this case LS, could affect employees' withdrawal behaviour (negative behaviour). The findings of this study suggest that LS has no significant influence on nurses' delivery of SQ, which in this particular case, SQ is a positive behaviour. Perhaps, the possible explanation to 
this finding is that a non-work variable has an impact on negative behaviour (employees' withdrawal) as proposed by Beutell (2006) but it has no direct significant influence on positive behaviour such as delivering high SQ.

The findings of the present study have several managerial implications for the management of public hospitals in Malaysia. First, QWL is the antecedent of nursing SQ and initiatives to improve nursing QWL would lead to nurses providing quality service. Thus, the hospital management could address nursing shortage by addressing aspects that would enhance their QWL such as addressing to their needs for, what are termed as, "communication and opportunities for career growth" and "work-family life balance". The needs for "communication and opportunities for career growth" could be addressed by providing a conducive work environment that permits participatory decision-making, free flow of vertical and horizontal communication, opportunities for career advancement and create the feeling of "work family" belonging among staff.

Second, this study also indicates that achieving work-family life balance is important among the nursing workforce. Tausig and Fenwick (2001) reported that "voluntary alternate scheduling" could reduce work-life time imbalance. Therefore, the hospital management perhaps should consider implementing "voluntary alternate scheduling”, where nurses have some choice or control over the hours or days worked instead of involuntary scheduling where nurses have no choice as to time or days worked. The hospital management should treat nurses as "assets" to an organisation instead of perceiving them as "cost" and allow them to participate in managing their work and making decisions.

\section{Suggestions for Future Research}

The study was conducted not without limitations. This study only concentrated on nurses in the health-care sector, and did not include employees from other industries such as financing and educational industries. Therefore, the results of this study should not be generalised to other industries as different work cultures, human resources practices, and management systems might affect employees' perceptions towards QWL, SQ and LS in a different manner. Future researchers could widen the scope of this study by including employees from other industries and perform a comparative study across different industries. The study was conducted using a quantitative research approach and data was collected using questionnaires. Therefore, the results of this study were limited to providing numerical descriptions rather than a detailed narrative and generally provide less elaborate accounts of human perception. The development of structured standard questions could lead to false representation, where the data actually reflects the view of the researcher instead of the participating subjects. Future research should undertake to overcome the lack of depth and insight of a qualitative study. Conducting qualitative research is suggested to overcome the limitations of quantitative research by identifying the important issues and then confirm their validity through quantitative research. 


\section{References}

Abdullah, T., (1998), "The Satisfaction With Life Scale (SWLS): Psychometric Properties in an Arabic Speaking Sample”, International Journal of Adolesence and Youth, vol.7, pp. 113-119.

Arrindell, W. A., Heesink, J., \& Feiji, J. A., (1999), "The Satisfaction With Life scale (SWLS): Appraisal with 1700 Health Young Adults in the Netherlands”, Personality and Individual Differences, vol. 26, pp. 815-826.

Berry, L. and Parasuraman, A., (1991). Marketing Services: Competing Through Quality, The Free Press, Oxford.

Beutell, N. J., (2006), "Life satisfaction in Relation to Domain Satisfaction, Mental Health, and Physical Health", http://wfnetwork.bc.edu/encyclopedia_entry.php?id=3283\&area=academics, assessed on 23 January 2010.

Brady, M. K. and Cronin, J. J., (2001), "Some new thought on conceptualizing perceived service quality: a hierarchical approach”, Journal of Marketing, vol. 65, pp. 33-49

Bryne, B.M., (2009), Structural Equation Modeling With AMOS Basic Concepts, Applications, and Programming, $2^{\text {nd }}$ edition, Taylor and Francis Group, NY.

Brooks, B. A., and Anderson, M. A., (2005), "Defining Quality of Nursing Work Life. Nursing Economics”, Vol. 23, no.6, pp. 319-326.

Burns, A. C., and Bush, R. F., (2010), Marketing Research, (6th ed.), Pearson Prentice Hall, New Jersey

Demaerouti, E., Bakker, A.B., Nachreiner, F. and Schaufeli, W., (2000), "A Model of Burnout and Life Satisfaction Amongst Nurses”, Journal of Advance Nursing, vol.3, no.2, pp. $452-464$.

Diener, E., Emmons, R. A., Larson, R. J., and Griffin, S., (1985), 'The Satisfaction With Life Scale', Journal of Personality Assessment, vol. 49, no 1, pp. 71-75.

Field, A., (2009), Discovering Statistics Using SPSS, $3^{\text {rd }}$ edition, SAGE Publication Ltd., London.

Fornell, C., and Larcker D. F., (1981). "Evaluating Structural Equation Models with Unobservable Variables and Measurement Error”, Journal of Marketing Research, vol. 18, February, pp. 39-50.

Gouveia, V. V., Milfont, T. L., Nunes, F., and Coelho, J. M., (2009), "Life Satisfaction in Brazil: Testing the Psychometric Properties of the Satisfaction With The Life Scale (SWLS) in Five Brazilian Samples”, Social Indicators Research, vol. 90, pp. 267277.

Hair, F.H., William, C.B., Barry, J.B., Rolph, E.A., Ronald, L.T., (2010), Multivariate Data Analysis, $7^{\text {th }}$ Edition, Prentice Hall, Upper-Saddle River, New Jersey.

Hackman,J.L., and Oldhams, G.R., (1980), Work Redisign, Reading, M.A: Addison-Wesley. 
Heskett, J.R. and Sasser. W.E., and Schlesinger, L.A., (1977), The Service Profit Chain, The Free Press, New York.

Hoe, S. L. (2008), "Issues and Procedures in Adopting Structural Equation Modeling Technique”, Journal of Applied Quantitative Methods, vol. 3, no. 1, pp. 76-83.

Kilbourne, W. E., Duffy, J. A., Duffy, M., and Giarchi, G., (2004), “The Applicability of SERVQUAL in Cross-National Measurements of Health-Care Quality”, Journal of Services Marketing, vol. 18, no.7, pp. 524-533.

Lawler, E. E., III, (1982), "Strategies for Improving the Quality of Work Life”, American Psychologist, vol. 37, pp. 486-693.

Lee, M. A., and Yom, Y.H., (2007), “A Comparative Study of Patients' and Nurses' Perceptions of the Quality of Nursing Services, Satisfaction and Intent to Revisit the Hospital: a Questionnaire Survey:, International Journal of Nursing Studies, vol. 44, pp. 545-555.

Kotler, P., Keller, K.L., Ang, S.H., Leong, S.M., and Tan, C.T., (2009). Marketing Management: An Asian Perspective, $5^{\text {th }}$ edition, Prentice Hall International, Inc., Singapore.

Lehtinen, JR and Lehtinen, U., (1982), "Service quality: a study of quality dimensions", unpublished Working Paper, Service Management Institute, Helsinki.

Manaf, N. H. A., (2005), "Quality Management in Malaysian Public Health Care", International Journal of Health Care Quality Assurance, vol. 18, no. 3, pp. 204-216.

Md-Sidin, Samsinar and Sambasivan, Murali, (2010), "Relationship between work-family conflict and quality of life: an investigation into the role of social support", Journal of Managerial Psychology, vol. 25(1), pp. 58-81.

Ministry of Health Malaysia, (2009), "Health Facts”, http://www. moh.gov.my/MohPortal/statPublic.jsp, assessed 9 September 2010.

Parasuraman, A., Zeithaml, V.A. and Berry, L.L., (1985), “A Conceptual Model of Service Quality and Its Implications for Future Research”, Journal of Marketing, vol.49, Fall, pp. 41-50.

Parasuraman A, Zeithmal, V.A. and Berry, L.L., (1988), "SERQUAL: A Multi-item Scale for Measuring Consumer Perceptions of Service Quality”, Journal of Retailing, vol. 64, Spring, pp. 12- 39.

Pavot, W. abd Diener, E., (1993), "Review of the Satisfaction with Life Scale", Psychological Assessment, vol. 5, no. 2, pp. 164-172.

Rice, R. W. (1984), “Organizational Work and the Overall Quality of Life”, Applied Social Psychology Annual, vol.5, pp. 155 -5178.

Sachs, J. (2004), "Validation of the Satisfaction With Life Scale in a Sample of Hong Kong University Students”, Psychologia, vol.46, pp. 225-234. 
Saklani D.R., (2004), "Quality of Work Life in the Indian Context: An Empirical Investigation”, Decision, vol. 31, no. 2, July-December, pp. 101-135.

Sandrick K., (2003), "Putting the emphasis on employees as an award. Winning employer, Baptist health care has distant memories of the workforce shortage", Trustee, January, pp. 6-10.

Sekaran, U., (2006), Research Method for Business: A Skill Building Approach, $4^{\text {th }}$ edition, John Wiley \& Sons, Inc New York.

Sirgy, M. J., Efraty, D., Siegel, P., and Dong-Jin, L. (2001), “A New Measure of Quality of Work Life (Qwl) Based on Need Satisfaction and Spillover Theories”, Social Indicators Research, vol. 55, pp. 241-302.

Sureshchandar, G. S., Chandrasekharan, R. and Kamalanabhan, T. J., (2001), "Customer perception of service quality: A critique”, Total Quality Management \& Business Excellence, vol. 12, Issue 1 January, pp. $111-124$.

Swami, V., and Chamorro-Premuzic, T., (2009), "Psychometric Evaluation of the Malay Satisfaction With Life Scale” Social Indicators Research, vol. 92, no. 1 pp. 25-33.

Taner, T., and Anthony, J. (2006), "Comparing Public and Private Hospital Care Service Quality in Turkey”, Leadership in Health Services, vol.19, no. 2, pp. i-x.

Tausig, M. and Renwick, R., (2001), "Unbinding Time: Alternate Work Schedules and Work-Life Balance”, Journal of Family and Economic Issues, vol. 22, no. 2, pp.101 -119 .

Wisniewski, M., \& Wisniewski, H. (2005), "Measuring Service Quality in a Hospital Colposcopy Clinic”, International Journal of Health Care Quality Assurance, vol. 18, no. 3, pp. 217-228. 